\title{
Single-particle characterization of biomass burning organic aerosol (BBOA): evidence for non-uniform mixing of high molecular weight organics and potassium
}

\author{
Alex K. Y. Lee ${ }^{1}$, Megan D. Willis ${ }^{1}$, Robert M. Healy ${ }^{2,3, a}$, Jon M. Wang ${ }^{3}$, Cheol-Heon Jeong $^{3}$, John C. Wenger ${ }^{2}$, \\ Greg J. Evans ${ }^{3}$, and Jonathan P. D. Abbatt ${ }^{1}$ \\ ${ }^{1}$ Department of Chemistry, University of Toronto, Toronto, Canada \\ ${ }^{2}$ Department of Chemistry and Environmental Research Institute, University College Cork, Cork, Ireland \\ ${ }^{3}$ Southern Ontario Centre for Atmospheric Aerosol Research, Department of Chemical Engineering \\ \& Applied Chemistry, University of Toronto, Toronto, Canada \\ anow at: Environmental Monitoring and Reporting Branch, Ontario Ministry of the Environment \\ and Climate Change, Toronto, Canada
}

Correspondence to: A. K. Y. Lee (alexky.lee@utoronto.ca)

Received: 27 October 2015 - Published in Atmos. Chem. Phys. Discuss.: 17 November 2015

Revised: 11 April 2016 - Accepted: 15 April 2016 - Published: 4 May 2016

\begin{abstract}
Biomass burning organic aerosol (BBOA) can be emitted from natural forest fires and human activities such as agricultural burning and domestic energy generation. BBOA is strongly associated with atmospheric brown carbon $(\mathrm{BrC})$ that absorbs near-ultraviolet and visible light, resulting in significant impacts on regional visibility degradation and radiative forcing. The mixing state of BBOA can play a critical role in the prediction of aerosol optical properties. In this work, single-particle measurements from a Soot-Particle Aerosol Mass Spectrometer coupled with a light scattering module (LS-SP-AMS) were performed to examine the mixing state of BBOA, refractory black carbon $(\mathrm{rBC})$, and potassium (K, a tracer for biomass burning aerosol) in an air mass influenced by wildfire emissions transported from northern Québec to Toronto, representing aged biomass burning plumes. Cluster analysis of singleparticle measurements identified five BBOA-related particle types. rBC accounted for 3-14 wt \% of these particle types on average. Only one particle type exhibited a strong ion signal for $\mathrm{K}^{+}$, with mass spectra characterized by low molecular weight organic species. The remaining four particle types were classified based on the apparent molecular weight of the BBOA constituents. Two particle types were associated with low potassium content and significant amounts of high molecular weight (HMW) organic compounds. Our obser-
\end{abstract}

vations indicate non-uniform mixing of particles within a biomass burning plume in terms of molecular weight and illustrate that HMW BBOA can be a key contributor to lowvolatility BrC observed in BBOA particles. The average mass absorption efficiency of low-volatility BBOA is about 0.8 $1.1 \mathrm{~m}^{2} \mathrm{~g}^{-1}$ based on a theoretical closure calculation. Our estimates indicate that low-volatility BBOA contributes $\sim 33$ $44 \%$ of thermo-processed particle absorption at $405 \mathrm{~nm}$; and almost all of the BBOA absorption was associated with lowvolatility organics.

\section{Introduction}

Biomass burning is one of the major global sources of primary particulate matter, contributing approximately 42 and $74 \%$ of global black carbon (BC) and primary organic aerosol, respectively (Bond et al., 2004). Although typical climate forcing calculations only consider $\mathrm{BC}$ and dust as light-absorbing aerosol components, there is growing evidence that atmospheric brown carbon (BrC, i.e. light-absorbing organic particulate matter with wavelengthdependent absorption in the ultraviolet-visible spectral region) is strongly associated with biomass burning organic aerosol (BBOA), resulting in significant impacts on regional 
visibility and radiative forcing (Kirchstetter et al., 2004; Chen and Bond, 2010; Lack et al., 2012, 2013; Saleh et al., 2014; Lu et al., 2015; Washenfelder et al., 2015).

Recent laboratory studies have investigated the physicochemical and optical properties of $\mathrm{BrC}$ from biomass burning emissions in order to improve understanding of its climate impacts. McMeeking et al. (2014) performed a series of thermodenuder experiments to examine volatility and absorption properties of laboratory-generated BBOA associated with BC. Compared to the evaporative loss of aerosol mass, lower removal efficiencies of aerosol absorption at the wavelengths of 405 and $532 \mathrm{~nm}$ were observed, implying the presence of less volatile, light-absorbing $\mathrm{BrC}$ in the thermoprocessed particles. Saleh et al. (2014) also demonstrated that the effective absorptivity of $\mathrm{BrC}$ that was generated from various biomass burning experiments is a function of the black carbon-to-organic aerosol (BC-to-OA) ratio and is largely associated with extremely low-volatility organic compounds (ELVOCs) that could not be removed efficiently by a thermodenuder operated at $250^{\circ} \mathrm{C}$. Mohr et al. (2013) recently identified nitrated phenol compounds as potentially important contributors to $\mathrm{BrC}$ in BBOA. However, the chemical characteristics of such extremely low-volatility $\mathrm{BrC}$ remain largely uncertain.

High molecular weight (HMW) organic compounds can be one of the major contributors to low-volatility $\mathrm{BrC}$ in BBOA. A significant number of HMW organic compounds in BBOA have been observed based on different mass spectrometry analyses (e.g. Elias et al., 1999; Smith et al., 2009). More importantly, Di Lorenzo and Young (2016) recently reported that most $\mathrm{BrC}$ absorption of BBOA extracts arises from HMW compounds based on size exclusion chromatography. Dinar et al. (2008) demonstrated that the absorptivity of ambient humic-like substance (HULIS, fulvic acid type) separated from BBOA extracts was enhanced with increasing molecular weight (from 340 to $460 \mathrm{Da}$ ), and thus decreasing aerosol volatility. Sun et al. (2007) also reported that the molecular structures of organic compounds that result in absorption spectra similar to that of atmospheric $\mathrm{BrC}$ are generally highly oxygenated molecules with more than 18 carbon atoms.

Co-emission of $\mathrm{BC}$ and BBOA from biomass burning sources can lead to internal mixing of these components. Potassium $(\mathrm{K})$ is abundant in biomass burning plumes and can be used as a tracer of biomass burning aerosol particles. Potassium salts such as $\mathrm{KCl}, \mathrm{KNO}_{3}$, and $\mathrm{K}_{2} \mathrm{SO}_{4}$ are hygroscopic in nature, and hence the mixing states of potassium salts, BC, and BBOA may affect the cloud formation ability and light scattering of individual biomass burning particles. Furthermore, the mixing state of biomass burning aerosol particles can be potentially used as a tracer of different types of burning. Internal mixtures of organic, BC, and potassium salts have been observed in biomass burning aerosol to different extents using electron microscopy techniques ( $\mathrm{Li}$ et al., 2003). Due to analytical challenges in single-particle char- acterization, there is limited knowledge of the mixing state of HMW organic compounds in BBOA. Our recent field studies have successfully demonstrated that a Soot-Particle Aerosol Mass Spectrometer (Aerodyne Research Inc., Billerica, MA) equipped with a light scattering module (LS-SPAMS) can quantify the mixing state of refractory black carbon (rBC) and organic aerosol in urban environments on a single-particle basis (Lee et al., 2015; Willis et al., 2016). Here, we extend the application of this single-particle measurement technique to investigate the mixing state of BBOA and other co-emitted species. The primary objective of this study is to investigate the mixing state of potassium, $\mathrm{rBC}$, and organic aerosol in aged biomass burning particles, which in this case originated from wildfire emissions transported from northern Québec to Toronto, Ontario. We use singleparticle measurements to provide chemical insight into the volatility and optical properties of biomass burning particles observed in this study.

\section{Experiment}

\subsection{Sampling detail and instrumentation}

Measurements were performed at the Southern Ontario Centre for Atmospheric Aerosol Research Facility, located in downtown Toronto $\left(43.66^{\circ} \mathrm{N}, 79.40^{\circ} \mathrm{W}\right)$. The sampling period was 12-17 June 2013, and encompassed an air mass heavily influenced by biomass burning (14 June, 14:00 LT to 16 June, 11:00 LT) attributed to wildfire events in Québec (Healy et al., 2015; Willis et al., 2016). The biomass burning influenced air mass took approximately 2 days transporting from Québec to Toronto based on back trajectory analysis (Hybrid Single-Particle Lagrangian Integrated Trajectory (HYSPLIT) Model). All instruments were connected to a common sampling line (a $10 \mathrm{~cm}$ inner diameter stainless steel tube) with a total flow rate of $170 \mathrm{~L} \mathrm{~min}^{-1}$. The stainless steel sampling line was connected to a $2.5 \mu \mathrm{m}$ cut-off inlet, located $15 \mathrm{~m}$ from the roadside and $3 \mathrm{~m}$ above ground level.

A Soot-Particle Aerosol Mass Spectrometer (Aerodyne Research Inc., Billerica, MA) equipped with a light scattering module (LS-SP-AMS) was the key instrument for this analysis (see Sect. 2.2-2.3). Other co-located aerosol instruments included an Aerosol Time-of-Flight Mass Spectrometer (ATOFMS 3800, TSI Inc., Shoreview, MN), a Photoacoustic Soot Spectrometer (PASS-3, Droplet Measurement Techniques, Boulder, CO), an Aerosol Chemical Speciation Monitor (ACSM, Aerodyne Research Inc., Billerica, MA), and a Scanning Mobility Particle Sizer (SMPS, Model 3936N76, TSI Inc., Shoreview, MN). The ACSM was used to quantify the ambient mass concentration of nonrefractory particulate matter (NR-PM) (Ng et al., 2011) with a time resolution of $30 \mathrm{~min}$ in this study (see details in the Supplement). A thermodenuder (Dekati Inc., Finland), op- 
erated at $250{ }^{\circ} \mathrm{C}$ with a flow rate of $6 \mathrm{~L} \mathrm{~min}{ }^{-1}$, was used to remove coating materials associated with $\mathrm{rBC}$ particles. The residence time for particles in the heated section of the thermodenuder was $1.9 \mathrm{~s}$ and the particle transmission efficiency was approximately $72 \%$ (Healy et al., 2015). The PASS3 and SMPS switched between sampling ambient aerosol and denuded aerosol every 10 min using an automated sampling valve. The details of ATOFMS, PASS-3, and thermodenuder for this field campaign have been reported in Healy et al. (2015).

\subsection{Soot-Particle Aerosol Mass Spectrometer}

An LS-SP-AMS was used to investigate the mixing state of rBC-containing particles on a single-particle basis. The working principle of the LS-SP-AMS has been reported elsewhere (Onasch et al., 2012; Lee et al., 2015). In brief, rBCcontaining particles are vaporized at $\sim 4000 \mathrm{~K}$ by a $1064 \mathrm{~nm}$ continuous wave intracavity infrared laser, similar to that of the single-particle soot photometer (SP2, Droplet Measurement Technologies) (Onasch et al., 2012). The resulting vapour is ionized via $70 \mathrm{eV}$ electron impact and then detected by a high-resolution time-of-flight mass spectrometer operated in V-mode, which provides a mass resolving power of $\sim 2000$ at $\mathrm{m} / z 28$ (DeCarlo et al., 2006; Canagaratna et al., 2007). A resistively heated tungsten vaporizer was removed from our instrument; therefore only $\mathrm{rBC}$ and its coating materials were detected (Massoli et al., 2015; Willis et al., 2016). A single slit chopper with $\sim 2 \%$ throughput was used. The LS-SP-AMS was operated at $1 \mathrm{~min}$ time resolution alternating between bulk mass spectrum (MS), particle time-of-flight (pToF), and single-particle modes throughout the study.

Direct calibration of the ionization efficiency for nitrate $\left(\mathrm{IE}_{\mathrm{NO}_{3}}\right)$ is not possible without the tungsten vaporizer. Before removal of the tungsten vaporizer from the LS-SP-AMS, ammonium nitrate $\left(\mathrm{NH}_{4} \mathrm{NO}_{3}\right)$ particles generated by a constant output atomizer (TSI Inc., Model 3076) were dried using a diffusion dryer, and subsequently size-selected at $300 \mathrm{~nm}$ using a differential mobility analyser (DMA, TSI Inc., Model 3081) for determining the mass-based ionization efficiency of nitrate $\left(\mathrm{mIE}_{\mathrm{NO}_{3}}\right)$. Similarly, the LS-SP-AMS was calibrated for $\mathrm{rBC}$ quantification using dried $300 \mathrm{~nm}$ Regal Black particles (Regal 400R Pigment Black, Cabot Corp.), a calibration standard recommended by Onasch et al. (2012) to determine the mass-based ionization efficiency of $\mathrm{rBC}\left(\mathrm{mIE}_{\mathrm{rBC}}\right)$. The mass of individual dried $300 \mathrm{~nm}$ Regal Black particles was $\sim 11.2 \mathrm{fg}$ based on aerosol particle mass analyser measurements (APM model 3600, Kanomax Inc.) (Willis et al., 2014). The relative ionization efficiency of $\mathrm{rBC}\left(\mathrm{RIE}_{\mathrm{rBC}}=\mathrm{mIE} \mathrm{rBC}_{\mathrm{rBC}} / \mathrm{mIE}_{\mathrm{NO}_{3}}\right)$ was $0.2 \pm 0.05(1 \sigma$ uncertainty). Assuming that $\mathrm{RIE}_{\mathrm{rBC}}$ remains unchanged, $\mathrm{mIE}_{\mathrm{NO}_{3}}$ and $\mathrm{IE}_{\mathrm{NO}_{3}}$ were calculated based on measured values of $\mathrm{mIE}_{\mathrm{rBC}}$ (after removing the tungsten vaporizer) and the known $\mathrm{RIE}_{\mathrm{rBC}}$. The average of the calculated $\mathrm{mIE}_{\mathrm{rBC}}$ values was $189 \pm 20$ ions pg $^{-1}$ based on four independent calibrations performed throughout the study. The calculated $\mathrm{IE}_{\mathrm{NO}_{3}}$ was then used with recommended RIE values (Jimenez et al., 2003 , i.e. nitrate $=1.1$, sulfate $=1.2$, organics $=1.4$, and ammonium $=4$ ) to quantify non-refractory aerosol species associated with $\mathrm{rBC}$ (referred to as NR-PM $\mathrm{rBC}_{\mathrm{rC}}$ ). Note that our previous studies have shown that the uncertainties of the recommended RIE for NR-PM $\mathrm{rBC}_{\mathrm{rBC}}$ for the SP-AMS can be up to $50 \%$ (Willis et al., 2014; Lee et al., 2015).

The ensemble MS and pToF data were processed using the AMS data analysis software (Squirrel, version $1.51 \mathrm{H}$ for unit mass resolution (UMR) data and Pika, version $1.10 \mathrm{H}$ for high-resolution peak fitting, downloaded from http://cires.colorado.edu/jimenez-group/ ToFAMSResources/ToFSoftware/index.html) with the corrected air fragment column of the standard fragmentation table (Allan et al., 2004; DeCarlo et al., 2006). Signals for rBC were quantified by the sum of carbon ion clusters $\left(\mathrm{C}_{x}^{+}\right.$, i.e. $\mathrm{C}_{1}^{+}-\mathrm{C}_{9}^{+}$) using high-resolution mass spectral data. The average $\mathrm{C}_{1}^{+}$to $\mathrm{C}_{3}^{+}$ratio (0.6) obtained from Regal Black calibration was used to correct the interference in $\mathrm{C}_{1}^{+}$from the non-refractory organics in ambient aerosol. Collection efficiency (CE) for $\mathrm{rBC}$ particles was determined in this study using beam width probe measurements described previously (Willis et al., 2014). Ambient rBC-containing particles had an average beam width $(\sigma)=0.46 \pm 0.03 \mathrm{~mm}$, and hence a $\mathrm{CE}$ of 0.6 was applied for absolute quantification of $\mathrm{rBC}$ and NR-PM $\mathrm{rBC}_{\mathrm{rBC}}$ (Willis et al., 2014). The CE applied does not impact calculations of mass fraction of $\mathrm{rBC}\left(\mathrm{mf}_{\mathrm{rBC}}\right)$ in the rBC-containing particles.

Positive matrix factorization (PMF) analysis that covered a wider range of the sampling period (i.e. 31 May-17 June 2015) was performed in our previous work to investigate the potential sources and characteristics of $\mathrm{rBC}$ and organic aerosol (Willis et al., 2016). In brief, the bilinear model was solved using the PMF2 algorithm in robust mode (Paatero and Tapper, 1994) and a final solution was selected using the PMF Evaluation Tool (PET) version 2.06 according to the method described by Ulbrich et al. (2009) and Zhang et al. (2011). A four-factor solution was selected by examining the solutions for up to eight PMF factors. Two factors allowed the separation of local/fresh traffic emissions from more aged/transported aerosol. Three factors allowed the separation of BBOA from a background oxygenated organic aerosol (OOA). Increasing the number of factors from three to four allowed for the separation of local/fresh traffic emissions into hydrocarbon-like organic aerosol (HOA)-rich and $\mathrm{rBC}$-rich factors. Moving beyond four factors, splitting, and/or mixing of BBOA and background OOA factors became evident, so solutions with more than four factors were not considered. Time series and mass spectra of the fourfactor solution are presented in Figs. S1 and S2 in the Supplement. 


\subsection{Single-particle measurements and data analysis}

The design and working principles of the LS module installed in different versions of the AMS have been previously described in detail (Cross et al., 2009; Freutel et al., 2013; Liu et al., 2013; Lee et al., 2015). The LS module consists of a $405 \mathrm{~nm}$ continuous wave laser (CrystaLaser, LC BCL-050405) that overlaps perpendicularly and completely with the particle beam $\sim 0.265 \mathrm{~m}$ downstream of the chopper (Cross et al., 2007). Scattered light from sampled particles is collected using an ellipsoidal mirror and detected with a photomultiplier tube. An LS signal can be obtained if a sampled particle is larger than the optical detection limit. The $50 \%$ cut-off mobility diameter $\left(d_{\mathrm{m}}\right)$ (i.e. a diameter that represents $50 \%$ counting efficiency of particle number when compared to a condensation particle counter) of the LS module determined using dried $\mathrm{NH}_{4} \mathrm{NO}_{3}$ particles is $\sim 250 \mathrm{~nm}$, which is approximately equal to a vacuum aerodynamic diameter $\left(d_{\mathrm{va}}\right)$ of $\sim 340 \mathrm{~nm}$ (the density and shape factor of $\mathrm{NH}_{4} \mathrm{NO}_{3}$ particles are $1.72 \mathrm{~g} \mathrm{~cm}^{-3}$ and 0.8 , respectively). Once a light scattering signal is detected, the computer is triggered to save the whole pToF trace, from which the single-particle mass spectrum is subsequently obtained.

Single-particle measurements were analysed based on a particle categorization procedure, fragmentation table modification, and k-means clustering algorithm described previously (Lee et al., 2015), except that $m / z 39\left(\mathrm{~K}^{+}\right)$was also included in the cluster analysis. In addition to the optical detection limit of the LS signal $(<0.2 \mathrm{~V})$, multiple scattering signals observed in a trigger event and particles generating weak total ion signals ( $<10$ ions) were excluded from cluster analysis. The size distribution of total ion signals of the single-particle measurement is shown in Fig. S3a and the orange dashed line represents the threshold values for real particles. The tungsten vaporizer was removed from the LS-SPAMS, and hence the instrumental background for $\mathrm{K}^{+}$predominantly due to surface ionization on the tungsten vaporizer was minimal. LS signals and single-particle mass spectra with unit mass resolution (UMR) were processed using the AMS LS data processing software (Sparrow, version1.04E, downloaded from http://cires.colorado.edu/jimenez-group/ ToFAMSResources/ToFSoftware/index.html). The built-in k-means clustering algorithm in IGOR Pro (WaveMetrics Inc., version 6.2.2.2) was used to analyse single-particle data for up to 25 clusters (Lee et al., 2015). Multiple clusters were manually merged into final particle classes if they exhibited similar mass spectral features and size distributions. Note that k-means clustering has been extensively applied to analyse single-particle data measured from the ATOFMS (Rebotier and Prather, 2007; Friedman et al.; 2009; Giorio et al., 2012; Gross et al., 2010; Healy et al.,2010, 2013; Pagels et al., 2013) and the results are highly consistent with other clustering algorithms such as ART-2a and hierarchical clustering (Rebotier and Prather, 2007; Giorio et al., 2012).
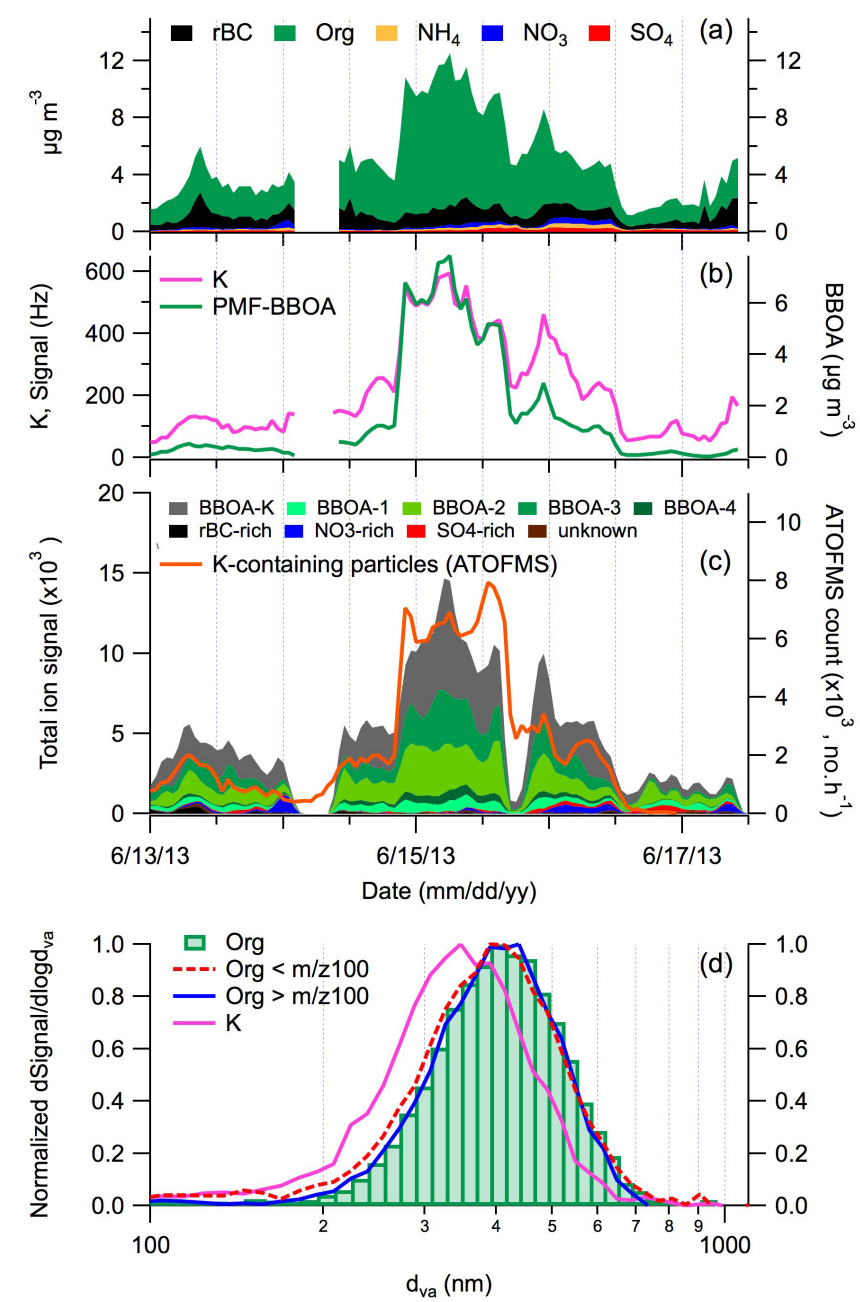

Figure 1. Time series of (a) $\mathrm{rBC}$ and $\mathrm{NR}-\mathrm{PM}_{\mathrm{rBC}}\left(\mathrm{Org}, \mathrm{SO}_{4}\right.$, $\mathrm{NO}_{3}, \mathrm{NH}_{4}$ ), (b) $\mathrm{K}^{+}$and PMF-BBOA factor measured by the LSSP-AMS, (c) number of K-containing particles measured by the ATOFMS (right axis) and total ion signal of all particle classes identified by cluster analysis of LS-SP-AMS data (left axis). (d) Size distributions of $\mathrm{K}^{+}$and Org associated with $\mathrm{rBC}$ measured by the LS-SP-AMS.

\section{Results and discussion}

\subsection{Observations of biomass burning influenced air mass}

A high loading of rBC-associated organics (referred to as $\mathrm{Org}_{\mathrm{rBC}}$ ) was observed during a period of strong biomass burning influence due to transported wildfire emissions originating from Québec (Fig. 1a, 14 June, 14:00 LT to 16 June, 11:00 LT, referred to as the BB period) (Healy et al., 2015). Potassium $\left(\mathrm{K}^{+}\right.$, a tracer of BBOA) measured by the LS-SPAMS is in good agreement with the K-containing particle number counts measured by the ATOFMS, and is strongly correlated with increased levels of $\operatorname{Org}_{\mathrm{rBC}}$ (Fig. 1a-c), indicating a significant contribution of BBOA to the total $\operatorname{Org}_{\mathrm{rBC}}$ 
Table 1. Summary of LS-SP-AMS single-particle cluster analysis.

\begin{tabular}{lrrrrr}
\hline $\begin{array}{l}\text { Particle } \\
\text { class }\end{array}$ & $\begin{array}{r}\text { Number of } \\
\text { particles }\end{array}$ & $\begin{array}{r}\text { Number } \\
\text { percentage }(\%)\end{array}$ & $\begin{array}{r}\text { Average mass fraction } \\
\text { of } \mathrm{rBC}\left(\mathrm{mf}_{\mathrm{rBC}}\right)\end{array}$ & $\begin{array}{r}\text { Average ion fraction } \\
\text { of } m / z 39\end{array}$ & $\begin{array}{r}\text { Average ion fraction } \\
\text { of } m / z 100-650\end{array}$ \\
\hline $\mathrm{SO}_{4}$-rich & 200 & 3 & 0.04 & 0.01 & 0.27 \\
$\mathrm{NO}_{3}$-rich & 344 & 5 & 0.05 & 0.02 & 0.05 \\
rBC-rich & 78 & 1 & 0.86 & 0.04 & 0.07 \\
BBOA-K & 1020 & 15 & 0.14 & 0.33 & 0.02 \\
BBOA-1 & 872 & 12 & 0.03 & 0.02 & 0.04 \\
BBOA-2 & 1645 & 24 & 0.03 & 0.02 & 0.23 \\
BBOA-3 & 1956 & 28 & 0.03 & 0.01 & 0.51 \\
BBOA-4 & 745 & 11 & 0.05 & - & 0.56 \\
Unknown & 139 & 2 & - & - \\
\hline
\end{tabular}

during the $\mathrm{BB}$ period. This is in good agreement with results of a PMF analysis, which indicate that a PMF-BBOA factor correlates well with $\mathrm{K}^{+}$(Fig. 1b) (Willis et al., 2016). The average mass fractions of $\mathrm{m} / \mathrm{z} 60$ (a marker ion for BBOA) and 44 to total organic $\left(f_{60}\right.$ and $\left.f_{44}\right)$ during the BB period were 0.013 and 0.09 , respectively, which is consistent with previous field observations for BBOA (Cubison et al., 2011). Even though $\mathrm{K}^{+}$and $\mathrm{Org}_{\mathrm{rBC}}$ observed within the BB period likely have the same origin, different peak positions in $\mathrm{K}^{+}$ and $\mathrm{Org}_{\mathrm{rBC}}$ size distributions measured by the LS-SP-AMS suggest non-uniform mixing of these two aerosol components in biomass burning emissions (Fig. 1d).

\subsection{Single-particle observations - BBOA particle types}

Cluster analysis of LS-SP-AMS single-particle mass spectra was performed to investigate the mixing states of $\mathrm{K}^{+}, \mathrm{Org}_{\mathrm{rBC}}$ and $\mathrm{rBC}$, yielding distinct particle classes (Table 1). Approximately $90 \%$ of the particles were classified into five BBOArelated particle types, namely BBOA-K, BBOA-1, BBOA-2, BBOA-3, and BBOA-4 (see discussion below). $\mathrm{rBC}$ was only a minor constituent of these particle classes $\left(\mathrm{mf}_{\mathrm{rBC}}=0.03-\right.$ 0.14 ), which is in agreement with the PMF-BBOA factor. Since a resistively heated tungsten vaporizer was removed from our LS-SP-AMS, only rBC and its coating materials were detected in this study. Assuming a core-shell structure, a spherical $\mathrm{rBC}$ core, a uniform thickness of coating, and a BBOA density of $1.3 \mathrm{~g} \mathrm{~cm}^{-3}$, the single-particle measurements can be used to calculate the coating thickness of the $\mathrm{rBC}$ core. To simulate the effect of the fractal structure of ambient $\mathrm{rBC}$, the effective density of $\mathrm{rBC}$ was varied between 0.3 and $1.4 \mathrm{~g} \mathrm{~cm}^{-3}$ (i.e. rBC core with different porosity). Figure $\mathrm{S} 4$ presents the two-dimensional histograms $\left(\mathrm{mf}_{\mathrm{rBC}}\right.$ vs. particle aerodynamic diameter, $d_{\mathrm{va}}$ ) of BBOA particles identified by cluster analysis, with calculated coating thickness curves overlaid for comparison. For example, a $320 \mathrm{~nm}$ BBOA particle (i.e. $d_{\mathrm{va}} \sim 400 \mathrm{~nm}$, assuming the effective densities of a porous $\mathrm{rBC}$ core and BBOA materials are 0.8 and $1.3 \mathrm{~g} \mathrm{~cm}^{-3}$, respectively) that consists of $5 \%$ of $\mathrm{rBC}$ by mass would have a $\mathrm{BC}$ core of radius $\sim 68 \mathrm{~nm}$ covered by $\sim 92 \mathrm{~nm}$ of BBOA material. The coating thickness is relatively insensitive to variations in the effective density of $\mathrm{rBC}$ core (Fig. S4).

An rBC-rich particle type with $\mathrm{mf}_{\mathrm{rBC}}$ of $\sim 0.8-0.9$ was identified in our previous observations in downtown Toronto, likely arising from fresh traffic exhaust (Lee et al., 2015; Willis et al., 2016). rBC-rich particles accounted for only about $1 \%$ of the total particles detected during this biomass burning episode, in part due to the lower cut-off size limitation of the LS module (Lee et al., 2015). A particle class associated with a high mass fraction of hydrocarbon-like organic aerosol materials (HOA-rich particle class reported in Lee et al., 2015) was not identified. Given that HOA-rich particles were clearly observed during the BB period based on the PMF results (Sect. 2.2 and Figs. S1 and S2), it is possible that the single-particle measurement of LS-SP-AMS actually detected a small number of HOA-rich particles during the BB period but cluster analysis could not separate them from the more dominant BBOA particle classes due to similar mass spectral characteristics. It is also important to note that cluster analysis over a wider range of the sampling period (i.e. 31 May-17 June 2015) in the same field study could identify the HOA-rich particle class as reported in our previous work (Willis et al., 2016). Accumulation-mode $\mathrm{SO}_{4}$-rich and $\mathrm{NO}_{3}$-rich (3 and $5 \%$ of particle number) particle classes with low $\mathrm{rBC}$ content $\left(\mathrm{mf}_{\mathrm{rBC}}<0.02\right)$ were also identified, similar to our previous observations in downtown Toronto (Lee et al., 2015).

\subsection{Mixing of $\mathrm{K}^{+}$in BBOA}

The five BBOA-related particle classes give relatively strong total ion signals within the BB period as illustrated in Fig. 1c, which is in good agreement with the PMF-BBOA factor and $\mathrm{K}^{+}$(Fig. 1b). Figure 2 demonstrates the average mass spectra (grey and green trace) of each BBOA-related particle class and the mass spectral histograms (normalized to the number of particles in each particle class, red trace) that show the relative frequency of a signal at each $m / z$. Only one particle type, BBOA-K, exhibits a strong ion signal at $m / z 39$, 


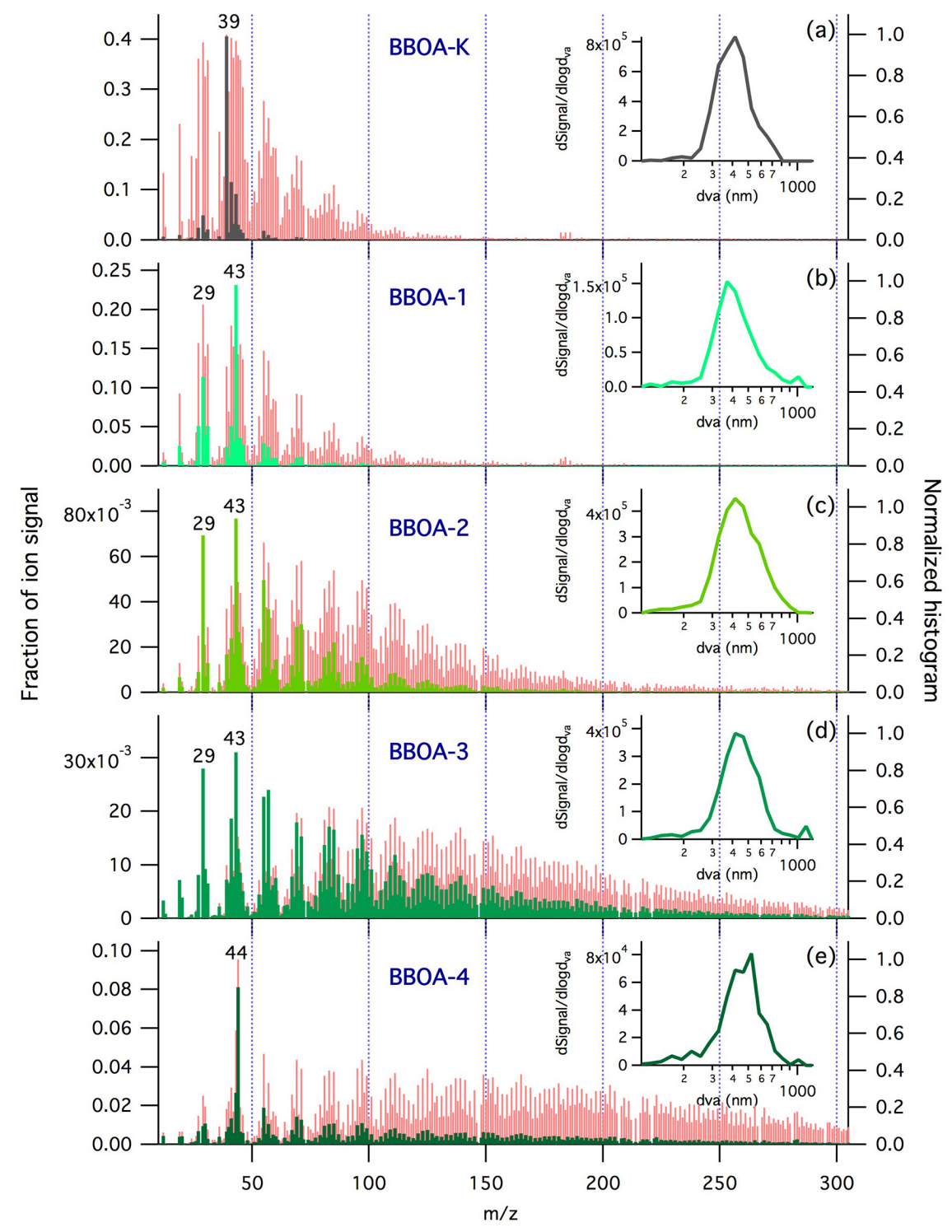

Figure 2. Average mass spectra (left axis, green/grey traces), normalized mass spectral histograms (showing the relative frequency of a signal at each $m / z$, right axis, red traces), and size distributions (insets) of the five BBOA-related particle classes identified by cluster analysis of LS-SP-AMS data.

with mass spectra characterized by low molecular weight organic fragment ions (Fig. 2a). The ion fraction of $\mathrm{m} / \mathrm{z} 39$ for BBOA-K and other BBOA-related particle classes is 0.33 and less than 0.02, respectively (Fig. 3a and Table 1). The inset in Fig. 3a presents the ion fraction distribution of $m / z, 39$ for BBOA-K (ranging from 0.1 to 0.8 ). Cluster analysis was performed using UMR mass spectra, and thus the relative contributions of $\mathrm{K}^{+}$and organic fragments to $\mathrm{m} / z 39$ cannot be distinguished. Nevertheless, the organic fragment (i.e. $\mathrm{C}_{3} \mathrm{H}_{3}^{+}$) at $m / z \quad 39$ only gives a small contribution to the mass spectra of PMF-BBOA factor determined by the highresolution ensemble measurements, suggesting that most of the ion signal at $m / z 39$ observed in the BBOA-K particle type is due to the presence of $\mathrm{K}^{+}$.

Ternary diagrams further illustrate the relative abundance of $\mathrm{K}^{+}$(representing the upper limit), $\mathrm{rBC}$, and organic ion signals in BBOA-K (Fig. 3b) and other BBOA-related particle types (Fig. S5). These observations highlight that (1) $\mathrm{K}^{+}$ is not uniformly mixed in BBOA although it has been extensively used as a tracer for BBOA, and (2) a large number fraction of BBOA particles are characterized by low $\mathrm{K}^{+}$and rBC content. In addition to primary emissions, large quantities of gas-phase organics co-emitted from biomass burning may lead to significant secondary organic aerosol (SOA) production, contributing to the observed BBOA-related particle 

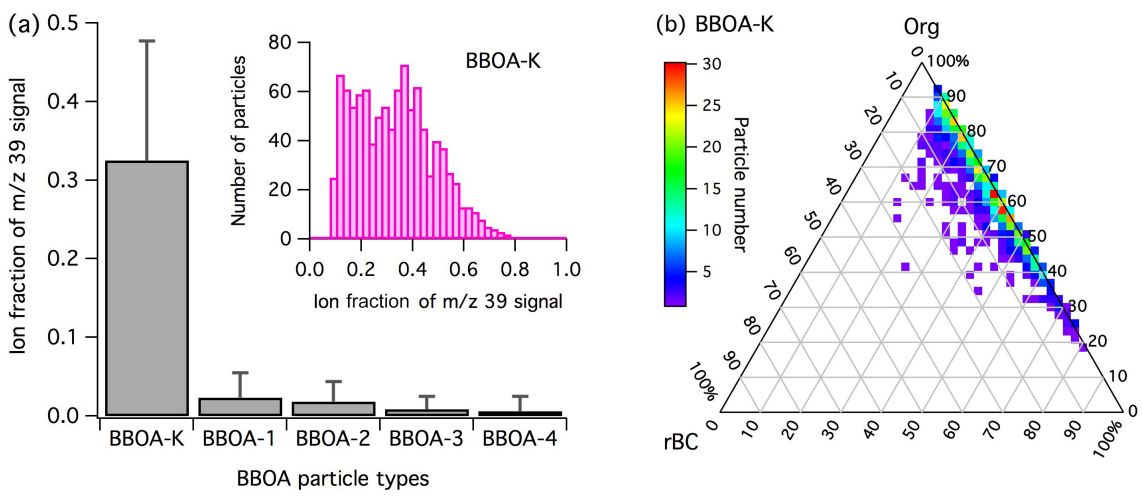

Figure 3. (a) Ion fraction of $m / z 39$ signal (a tracer of $\mathrm{K}^{+}$) for each BBOA-related particle class. Histogram of the ion fraction of $m / z 39$ for the BBOA-K particle class (inset). (b) Ternary plot of $\mathrm{rBC}, \mathrm{Org}_{\mathrm{BC}}$, and $\mathrm{K}$ ion signal for the five BBOA particle types.

types with low $\mathrm{K}^{+}$content. Assuming that the relative ionization efficiency of $\mathrm{K}^{+}\left(\mathrm{RIE}_{\mathrm{K}}\right)$ is equal to 2.9 (Drewnick et al., 2006) and using $m / z 39$ as a proxy for $\mathrm{K}^{+}$, the upper limits of average mass fractions of $\mathrm{K}^{+}$for BBOA-K and the other BBOA-related particle types are approximately 20 and $<1 \%$, respectively.

While BBOA-K accounted for $\sim 15 \%$ of the detected particle number (Table 1), our complementary ATOFMS measurements revealed that particles with a strong $\mathrm{K}^{+}$signal accounted for over $60 \%$ of the detected particle number for the same period. The comparison suggests that the LS-SPAMS measurement may underestimate potassium-rich particle number. However, ATOFMS is highly sensitive towards $\mathrm{K}^{+}$(Gross et al., 2000); thus even particles with low potassium mass content can exhibit high positive ion intensities for $\mathrm{K}^{+}$, but chemical matrix effects make the mass quantification of $\mathrm{K}^{+}$difficult. On the other hand, for the LS-SPAMS measurement, only $27 \%$ of the total particle number used in the clustering gave ion signals above the detection limit of $m / z 39$, which is approximately two ions as shown in Fig. S3b. Furthermore, $\mathrm{RIE}_{\mathrm{K}}$ is still uncertain for AMS measurements in general. Note that ATOFMS and LS-SP-AMS cannot detect BBOA particles that are without any components absorbing at a wavelength of $266 \mathrm{~nm}$ and in the absence of $\mathrm{rBC}$, respectively. Overall, a direct comparison between the two measurements is not straightforward as the mass quantifications of $\mathrm{K}^{+}$at the single-particle level for both instruments remain highly uncertain.

\subsection{Mixing of high molecular weight organic compounds in BBOA}

The remaining four BBOA particle types were classified according to the apparent molecular weight of BBOA constituents (Fig. 2b-e). The average value of $f_{60}$ for BBOA4 (0.004) is smaller than the values of other BBOA particle types (ranging from 0.008 to 0.015 ). Note that $\mathrm{m} / \mathrm{z} 44$ (a tracer ion for organic acids) is the main contributor to BBOA-4, whereas other BBOA particle types are dominated by ions at $m / z 29$ and 43 , suggesting that BBOA-4 is more oxidized relative to other BBOA particles. Based on the empirical parameterization of the improved ambient method reported by Canagaratna et al. (2015) and measured $f_{44}$ values from UMR mass spectra, the oxygen-to-carbon $(\mathrm{O}: \mathrm{C})$ ratio (i.e. $\left.\mathrm{O}: \mathrm{C}=0.079+4.31 \times f_{44}\right)$ of BBOA-4 is estimated to be 0.43 , which is higher than $\mathrm{O}: \mathrm{C}$ ratios of other BBOArelated particle types $(0.14-0.34)$. In addition to organics, $\mathrm{CO}^{+}$and $\mathrm{CO}_{2}^{+}$signals can be generated by rBC (Corbin et al., 2014), and thus our estimates likely represent the upper limit of $\mathrm{O}: \mathrm{C}$ ratios of each BBOA-related particle types.

Figure 4a illustrates the normalized cumulative histograms of mass-to-charge ratios (from $\mathrm{m} / \mathrm{z} 12$ to 628 , excluding $\mathrm{m} / \mathrm{z} 39$ and fragments with strong interferences from air and ammonium; see Lee et al., 2015) for each BBOA particle class, all BBOA particle types, and ensemble $\operatorname{Org}_{\mathrm{rBC}}$ within the BB period. Two particle types, BBOA-3 and BBOA-4, are associated with significant amounts of HMW organic fragments (i.e. more than $50 \%$ of the ion signal arose from organic fragments at $m / z 100$ or larger). For BBOA-2, $\sim 23 \%$ of the ion signal resides in HMW organic fragments. BBOA-K and BBOA-1 are mainly composed of low molecular weight organics with over $96 \%$ of their ion signal arising from organic fragments smaller than $m / z 100$. Further, a significant number of observed BBOA particles are composed of HMW organic fragments, up to $80 \%$ by mass (Fig. $4 \mathrm{~b}$ ). These observations demonstrate that (1) the mixing state of BBOA is not uniform in terms of organic molecular weight, and (2) a large number fraction of BBOA single-particle mass spectra $(\sim 40 \%)$ has major contributions from HMW organic fragment ions, which are detected even though a hard ionization technique (electron impact) was used in the LSSP-AMS.

HMW mass spectral signatures, some of which are associated with polycyclic aromatic hydrocarbons, were also observed in the ATOFMS data for the same period (see Fig. S8 for the average ATOFMS mass spectrum). However, those spectra only accounted for $\sim 0.5 \%$ of the total number of 

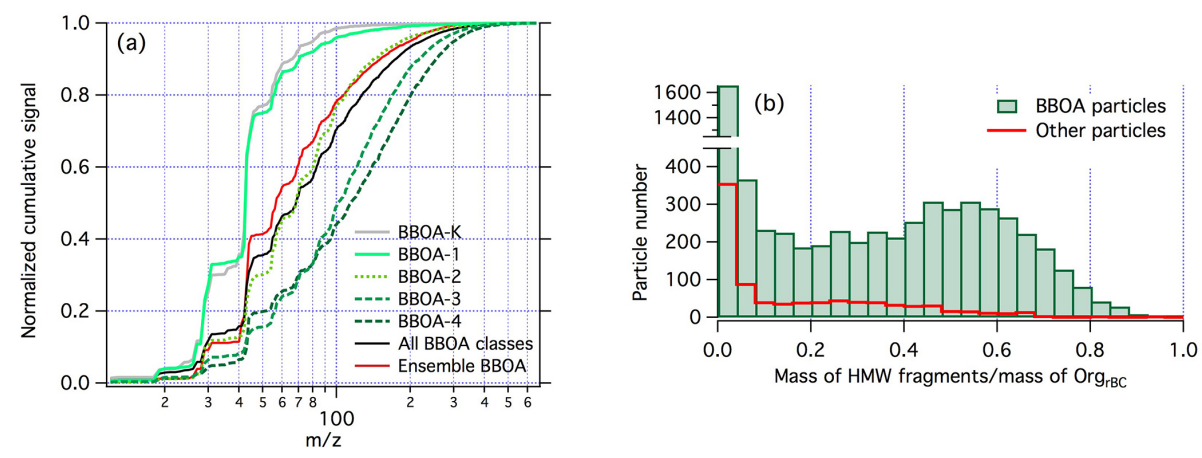

Figure 4. (a) Normalized cumulative histogram of mass-to-charge ratios for each BBOA-related particle class. (b) Histograms of the mass fraction of HMW organic fragments $(>m / z$ 100) in different particle types.

spectra detected by the ATOFMS during the BB period. Even though the ATOFMS has been previously demonstrated to detect HMW oligomeric species in both ambient air and chamber experiments (Gross et al., 2006; Denkenberger et al., 2007; Healy et al., 2010), its sensitivity towards HMW organics may be influenced by chemical matrix effects, making the detection and quantification of HMW organics in ambient particles challenging (Reilly et al., 2000).

Although the ensemble size distributions of $\mathrm{K}^{+}$and Org $_{\text {rBC }}$ are observably different (Fig. 1d), the size distributions of BBOA-K and other BBOA-related particle classes are similar to each other except that BBOA-4 peaks at a slightly larger particle diameter (the insets in Fig. 2a-e), likely due to measurement bias of the LS module towards larger particle sizes (Lee et al., 2015). Nevertheless, it is worth noting that there is no significant difference between the ensemble size distributions of low $(<m / z 100)$ and high $(>m / z$ 100) molecular weight organics (Fig. 1d). This suggests that ensemble size distributions are insufficient to visualize external mixing of the BBOA particle types with different average molecular weight, and also highlights the relevance and unique capabilities of single-particle mass spectrometry observations.

\subsection{Volatility and optical properties of BBOA}

To assess the volatility of BBOA, the mass fraction of total BBOA, regardless of $\mathrm{rBC}$ content, retained in thermoprocessed particles was estimated based on the SMPS and ACSM measurements (see details in Supplement). The removal efficiency of aerosol volume, based on SMPS measurements, was $60-80 \%$ for the majority of the sampling period and decreased to $\sim 40 \%$ on 15 June, when the site was most heavily impacted by the wildfire emissions (Fig. S6a). The estimation based on ACSM measurements also illustrates that approximately $60 \%$ of the total BBOA was retained in the thermo-denuded particles on 15 June to match the SMPS observations, given the fact that BBOA dominated the total aerosol mass on 15 June (Fig. S6b, see details in Supplement). However, the short residence time $(1.9 \mathrm{~s})$ of ambient aerosol particles in the thermodenuder may result in non-equilibrium measurements and thus overestimate lowvolatility aerosol mass (An et al., 2007; May et al., 2013).

A strong correlation between the thermo-denuded SMPS aerosol volume and the estimated low-volatility aerosol mass is observed for the entire sampling period $\left(R^{2}=0.93\right.$, blue open circles in Fig. 5a) when all $\mathrm{rBC}$ and $\sim 60 \%$ of the total $\mathrm{BBOA}$ is assumed to remain after the thermodenuder. The slope of the linear regression (blue dashed line) is $1.38 \mathrm{~g} \mathrm{~cm}^{-3}$, which can be interpreted as the average density of thermo-processed particles, assuming all particles are spherical and internally mixed, and is similar to the effective particle densities of biomass burning smoke observed in recent laboratory chamber experiments (1.18$1.45 \mathrm{~g} \mathrm{~cm}^{-3}$ ) (Li et al., 2015). In contrast, significant enhancement of $\mathrm{rBC}$ was not observed during the $\mathrm{BB}$ period and $\mathrm{rBC}$ only has a weak correlation with the aerosol volume of thermo-processed particles for the entire sampling period $\left(R^{2}=0.31\right.$, slope $=0.43 \mathrm{~g} \mathrm{~cm}^{-3}$, black solid circles and dashed line in Fig. 5a). Note that particle mobility diameter measured by SMPS is a function of particle shape and morphology. The non-spherical and fractal structure of $\mathrm{rBC}$ can lead to an underestimation of removal efficiency of aerosol mass in the thermodenuder. Although it seems unlikely, rBC mass alone may explain the observed aerosol volume of thermo-processed particles during the BB period only if their effective density is less than $0.3 \mathrm{~g} \mathrm{~cm}^{-3}$.

The absorption of thermo-denuded aerosol at a wavelength of $405 \mathrm{~nm}\left(B_{\mathrm{abs}}\right)$ was measured by the PASS-3 (Fig. S6d). Similar to the case of aerosol volatility, the strong absorption characteristics observed during the $\mathrm{BB}$ period cannot be explained by the presence of $\mathrm{rBC}$ alone, because the $\mathrm{rBC}$ loading was roughly constant throughout the sampling pe$\operatorname{riod}\left(R^{2}=0.33\right.$, black solid circles in Fig. $\left.5 \mathrm{~b}\right)$. The correlation between thermo-denuded particles and aerosol absorption at $405 \mathrm{~nm}$ is improved significantly if low-volatility BBOA ( $60 \%$ of the total BBOA) is included in the calculation $\left(R^{2}=0.84\right.$, blue open circles in Fig. $\left.5 \mathrm{~b}\right)$. The slope of the linear regression to these data (blue dashed line in 

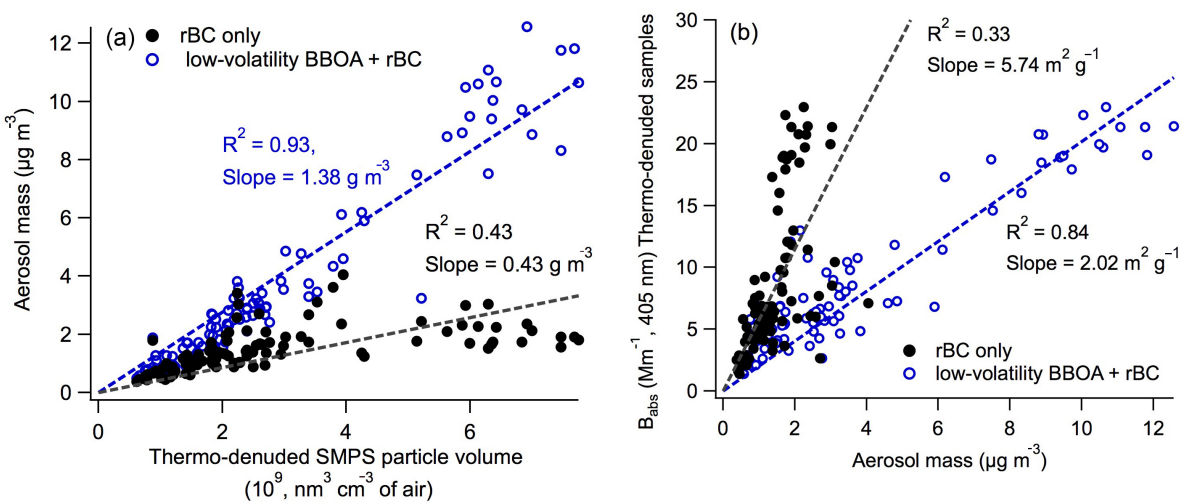

Figure 5. (a) Correlation of the estimated total of non- and low-volatility aerosol mass (rBC $+60 \%$ of the total BBOA) and thermodenuded particle volume measured by the SMPS. (b) Correlations of aerosol absorption at $405 \mathrm{~nm}$ of thermo-denuded particles $\left(B_{\text {abs }}\right)$ and the estimated total of non- and low-volatility aerosol mass.

Fig. 5b) is $2.02 \mathrm{~m}^{2} \mathrm{~g}^{-1}$, which can be interpreted as the average mass absorption efficiency (MAE) of thermo-processed particles at $405 \mathrm{~nm}$.

Our previous work reported that the absorption enhancement attributable to lensing at $781 \mathrm{~nm}$ was not observed for $\mathrm{rBC}$ during the BB period based on the PASS-3 measurement (Healy et al., 2015). Furthermore, a recent study has reported that the interference on absorption measurement due to pyrolysed ambient organic aerosol in a thermodenuder operated at $250^{\circ} \mathrm{C}$ is minimal (Liu et al., 2015). Therefore, these observations suggest that low-volatility BBOA components could be a key contributor to $\mathrm{BrC}$ in the thermodenuded particles. Assuming the MAE of $\mathrm{rBC}\left(\mathrm{MAE}_{\mathrm{rBC}}\right)$ from biomass burning ranged from 5.3 to $6.4 \mathrm{~m}^{2} \mathrm{~g}^{-1}$ (Lack et al., 2012), the average MAE of low-volatility BBOA (MAE $\mathrm{BBOA}_{\mathrm{A}}$ ) observed during the BBOA period is approximately equal to $0.8-1.1( \pm 0.4) \mathrm{m}^{2} \mathrm{~g}^{-1}$ based on a theoretical closure calculation (i.e. absorption at $405 \mathrm{~nm}$ measured by PASS- $3=m_{\mathrm{rBC}}\left(\mathrm{MAE}_{\mathrm{rBC}}\right)+m_{\mathrm{BBOA}}\left(\mathrm{MAE}_{\mathrm{BBOA}}\right)$, where $m_{i}=$ mass concentration of species $i$ ), which is comparable to MAE of primary organic aerosol emitted from biomass burning (e.g. Lack et al., 2012, 2013). The above estimation indicates that the low-volatility BBOA contributes approximately $33-44 \%$ of thermo-processed particle absorption at $405 \mathrm{~nm}$ during the BB period. Furthermore, Healy et al. (2015) showed that absorption of ambient and thermally denuded particles at $405 \mathrm{~nm}$ are comparable during the $\mathrm{BB}$ period, suggesting that almost all of the BBOA absorption was associated with low-volatility materials (Saleh et al., 2014; Di Lorenzo and Young, 2016).

Lastly, it is particularly important to note that the ion fractions of BBOA-2, BBOA-3, and BBOA-4 from the singleparticle measurements accounted for $\sim 61 \%$ of the total ion signal, which is equivalent to aerosol mass as most of the observed BBOA particles are dominated by organics, from all BBOA-related particle classes during the BB period. This implies that medium to high molecular weight organic compounds may contribute significantly to low-volatility $\mathrm{BrC}$ (i.e. $60 \%$ of the total BBOA) in the biomass-burningaffected atmosphere.

\section{Conclusions and atmospheric implications}

This is the first study to quantify the mixing state of BBOA, $\mathrm{K}^{+}$, and $\mathrm{rBC}$ in aged biomass burning plumes using the LSSP-AMS. BBOA-related particle types are composed of low $\mathrm{rBC}$ mass $\left(\mathrm{mf}_{\mathrm{rBC}} 0.03-0.14\right)$. Even though $\mathrm{K}^{+}$has been considered as a tracer of biomass burning aerosol particles, our results demonstrate that $\mathrm{K}^{+}$is not uniformly mixed in BBOA and that over $80 \%$ of $\mathrm{BBOA}$ particles observed here are characterized by low $\mathrm{K}^{+}$content (i.e. $<1 \mathrm{wt} \%$ by assuming $\mathrm{RIE}_{\mathrm{K}}$ of 2.9). High molecular weight organic compounds were clearly observed in some BBOA particles. A large fraction of BBOA particles (BBOA-3 and BBOA-4) detected in this study is composed of HMW organic compounds with low $\mathrm{rBC}$ and $\mathrm{K}^{+}$content.

Thermodenuder experiments indicate the presence of lowvolatility $\mathrm{BrC}$ in BBOA. Based on SMPS and aerosol mass spectrometry measurements, we estimated that about $60 \%$ of the total BBOA mass was retained in the thermoprocessed particles. This is consistent with recent observations, which demonstrated that laboratory-generated BBOA particles could be composed of extremely low-volatility $\mathrm{BrC}$ depending on the burning conditions and fuel types (Saleh et al., 2014). Liu et al. (2015) also observed low-volatility secondary $\mathrm{BrC}$ that was associated with large $\mathrm{rBC}$ particles in wintertime in the UK. Notably, BBOA-2, BBOA-3, and BBOA-4 accounted for $\sim 61 \%$ of ion signals from BBOArelated particle classes during the $\mathrm{BB}$ period, highlighting that medium to high molecular weight organic compounds may contribute significantly to low-volatility $\mathrm{BrC}$. The average mass absorption efficiency of low-volatility BBOA is about $0.8-1.1 \mathrm{~m}^{2} \mathrm{~g}^{-1}$ based on a theoretical closure calculation. The estimation indicates that the low-volatility BBOA 
contributes $\sim 33-44 \%$ of the thermo-processed particles' absorption at $405 \mathrm{~nm}$ during the BB period, and almost all of the BBOA absorption was associated with low-volatility organics. The observed non-uniform mixing state of BBOA in terms of molecular weight also suggests that it may be inappropriate to assume uniform distributions of aerosol volatility and absorption for BBOA particles.

\section{The Supplement related to this article is available online at doi:10.5194/acp-16-5561-2016-supplement.}

Acknowledgements. This work was financially supported by Natural Sciences and Engineering Research Council (NSERC) of Canada, the Canada Foundation for Innovation, and the Marie Curie Action FP7-PEOPLE-IOF-2011 (project: CHEMBC, no. 299755).

Edited by: E. Browne

\section{References}

Allan, J., Delia, A., Coe, H., Bower, K., Alfarra, M., Jimenez, J., Middlebrook, A., Drewnick, F., Onasch, T., Canagaratna, M., Jayne, J., and Worsnop, D.: A generalised method for the extraction of chemically resolved mass spectra from Aerodyne aerosol mass spectrometer data, J. Aerosol Sci., 35, 909-922, 2004.

An, W. J., Pathak, R. K., Lee, B., and Pandis, S. N.: Aerosol volatility measurement using an improved thermodenuder: Application to secondary organic aerosol, J. Aerosol Sci., 38, 305-314, 2007.

Bond, T. C., Streets, D. G., Yarber, K. F., Nelson, S. M., Woo, J. H., and Klimont, Z.: A technology-based global inventory of black and organic carbon emissions from combustion, J. Geophys. Res.-Atmos., 109, D14203, doi:10.1029/2003JD003697, 2004.

Canagaratna, M. R., Jayne, J. T., Jimenez, J. L., Allan, J. D., Alfarra, M. R., Zhang, Q., Onasch, T. B., Drewnick, F., Coe, H., Middlebrook, A., Delia, A., Williams, L. R., Trimborn, A. M., Northway, M. J., DeCarlo, P. F., Kolb, C. E., Davidovits, P., and Worsnop, D. R.: Chemical and microphysical characterization of ambient aerosols with the aerodyne aerosol mass spectrometer, Mass Spectrom. Rev., 26, 185-222, 2007.

Canagaratna, M. R., Jimenez, J. L., Kroll, J. H., Chen, Q., Kessler, S. H., Massoli, P., Hildebrandt Ruiz, L., Fortner, E., Williams, L. R., Wilson, K. R., Surratt, J. D., Donahue, N. M., Jayne, J. T., and Worsnop, D. R.: Elemental ratio measurements of organic compounds using aerosol mass spectrometry: characterization, improved calibration, and implications, Atmos. Chem. Phys., 15, 253-272, doi:10.5194/acp-15-253-2015, 2015.

Chen, Y. and Bond, T. C.: Light absorption by organic carbon from wood combustion, Atmos. Chem. Phys., 10, 1773-1787, doi:10.5194/acp-10-1773-2010, 2010.

Corbin, J. C., Sierau, B., Gysel, M., Laborde, M., Keller, A., Kim, J., Petzold, A., Onasch, T. B., Lohmann, U., and Mensah, A. A.: Mass spectrometry of refractory black carbon particles from six sources: carbon-cluster and oxygenated ions, Atmos. Chem. Phys., 14, 2591-2603, doi:10.5194/acp-14-2591-2014, 2014.
Cross, E. S., Slowik, J. G., Davidovits, P., Allan, J. D., Worsnop, D. R., Jayne, J. T., Lewis, D. K., Canagaratna, M., and Onasch, T. B.: Laboratory and ambient particle density determinations using light scattering in conjunction with aerosol mass spectrometry, Aerosol Sci. Technol., 41, 343-359, 2007.

Cross, E. S., Onasch, T. B., Canagaratna, M., Jayne, J. T., Kimmel, J., Yu, X.-Y., Alexander, M. L., Worsnop, D. R., and Davidovits, P.: Single particle characterization using a light scattering module coupled to a time-of-flight aerosol mass spectrometer, Atmos. Chem. Phys., 9, 7769-7793, doi:10.5194/acp-9-7769-2009, 2009.

Cubison, M. J., Ortega, A. M., Hayes, P. L., Farmer, D. K., Day, D., Lechner, M. J., Brune, W. H., Apel, E., Diskin, G. S., Fisher, J. A., Fuelberg, H. E., Hecobian, A., Knapp, D. J., Mikoviny, T., Riemer, D., Sachse, G. W., Sessions, W., Weber, R. J., Weinheimer, A. J., Wisthaler, A., and Jimenez, J. L.: Effects of aging on organic aerosol from open biomass burning smoke in aircraft and laboratory studies, Atmos. Chem. Phys., 11, 12049-12064, doi:10.5194/acp-11-12049-2011, 2011.

DeCarlo, P. F., Kimmel, J. R., Trimborn, A., Northway, M. J., Jayne, J. T., Aiken, A. C., Gonin, M., Fuhrer, K., Horvath, T., Docherty, K. S., Worsnop, D. R., and Jimenez, J. L.: Field-deployable, high-resolution, time-of-flight aerosol mass spectrometer, Anal. Chem., 78, 8281-8289, 2006.

Denkenberger, K. A., Moffet, R. C., Holecek, J. C., Rebotier, T. P., and Prather, K. A.: Real-time, single-particle measurements of oligomers in aged ambient aerosol particles, Environ. Sci. Technol., 41, 5439-5446, 2007.

Di Lorenzo, R. A. and Young, C. J.: Size separation method for absorption characterization in brown carbon: Application to an aged biomass burning sample, Geophys. Res. Lett., 43, 458-465, 2016.

Dinar, E., Riziq, A. A., Spindler, C., Erlick, C., Kiss, G., and Rudich, Y.: The complex refractive index of atmospheric and model humic-like substances (HULIS) retrieved by a cavity ring down aerosol spectrometer (CRD-AS), Faraday Discuss., 137, 279-295, 2008.

Drewnick, F., Hings, S. S., Curtius, J., Eerdekens, G., and Williams, J.: Measurement of fine particulate and gas-phase species during the New Year's fireworks 2005 in Mainz, Germany, Atmos. Environ., 40, 4316-4327, 2006.

Elias, V. O., Simoneit, B. R. T., Pereira, A. S., Cabral, J. A., and Cardoso, J. N.: Detection of high molecular weight organic tracers in vegetation smoke samples by high-temperature gas chromatography-mass spectrometry, Environ. Sci. Technol., 33, 2369-2376, 1999.

Freutel, F., Drewnick, F., Schneider, J., Klimach, T., and Borrmann, S.: Quantitative single-particle analysis with the Aerodyne aerosol mass spectrometer: development of a new classification algorithm and its application to field data, Atmos. Meas. Tech., 6, 3131-3145, doi:10.5194/amt-6-3131-2013, 2013.

Friedman, B., Herich, H., Kammermann, L., Gross, D. S., Arneth, A., Holst, T., and Cziczo, D. J.: Subarctic atmospheric aerosol composition: 1. Ambient aerosol characterization, J. Geophys. Res.-Atmos., 114, D13203, doi:10.1029/2009JD011772, 2009.

Giorio, C., Tapparo, A., Dall'Osto, M., Harrison, R. M., Beddows, D. C. S., Di Marco, C., and Nemitz, E.: Comparison of three techniques for analysis of data from an Aerosol Time-of-Flight Mass Spectrometer, Atmos. Environ., 61, 316-326, 2012. 
Gross, D. S., Galli, M. E., Silva, P. J., and Prather, K. A.: Relative sensitivity factors for alkali metal and ammonium cations in single particle aerosol time-of-flight mass spectra, Anal. Chem., 72, 416-422, 2000.

Gross, D. S., Galli, M. E., Kalberer, M., Prevot, A. S. H., Dommen, J., Alfarra, M. R., Duplissy, J., Gaeggeler, K., Gascho, A., Metzger, A., and Baltensperger, U.: Real-time measurement of oligomeric species in secondary organic aerosol with the aerosol time-of-flight mass spectrometer, Anal. Chem., 78, 2130-2137, 2006.

Gross, D. S., Atlas, R., Rzeszotarski, J., Turetsky, E., Christensen, J., Benzaid, S., Olson, J., Smith, T., Steinberg, L., Sulman, J., Ritz, A., Anderson, B., Nelson, C., Musicant, D. R., Chen, L., Snyder, D. C., and Schauer, J. J.: Environmental chemistry through intelligent atmospheric data analysis, Environ. Modell. Softw., 25, 760-769, 2010.

Healy, R. M., Hellebust, S., Kourtchev, I., Allanic, A., O'Connor, I. P., Bell, J. M., Healy, D. A., Sodeau, J. R., and Wenger, J. C.: Source apportionment of $\mathrm{PM}_{2.5}$ in Cork Harbour, Ireland using a combination of single particle mass spectrometry and quantitative semi-continuous measurements, Atmos. Chem. Phys., 10, 9593-9613, doi:10.5194/acp-10-9593-2010, 2010.

Healy, R. M., Sciare, J., Poulain, L., Crippa, M., Wiedensohler, A., Prévôt, A. S. H., Baltensperger, U., Sarda-Estève, R., McGuire, M. L., Jeong, C.-H., McGillicuddy, E., O’Connor, I. P., Sodeau, J. R., Evans, G. J., and Wenger, J. C.: Quantitative determination of carbonaceous particle mixing state in Paris using single-particle mass spectrometer and aerosol mass spectrometer measurements, Atmos. Chem. Phys., 13, 9479-9496, doi:10.5194/acp13-9479-2013, 2013.

Healy, R. M., Wang, J. M., Jeong, C.-H., Lee, A. K. Y., Willis, M. D., Jaroudi, E., Zimmerman, N., Hilker, N., Murphy, M., Eckhardt, S., Stohl, A., Abbatt, J. P. D., Wenger, J. C., and Evans, G. J.: Light-absorbing properties of ambient black carbon and brown carbon from fossil fuel and biomass burning sources, J. Geophys. Res.-Atmos., 120, 6619-6633, 2015.

Jimenez, J. L., Jayne, J. T., Shi, Q., Kolb, C. E., Worsnop, D. R., Yourshaw, I., Seinfeld, J. H., Flagan, R. C., Zhang, X. F., Smith, K. A., Morris, J. W., and Davidovits, P.: Ambient aerosol sampling using the Aerodyne Aerosol Mass Spectrometer, J. Geophys. Res.-Atmos., 108, 8425, doi:10.1029/2001JD001213, 2003.

Kirchstetter, T. W., Novakov, T., and Hobbs, P. V.: Evidence that the spectral dependence of light absorption by aerosols is affected by organic carbon, J. Geophys. Res.-Atmos., 109, D21208, doi:10.1029/2004JD004999, 2004.

Lack, D. A., Langridge, J. M., Bahreini, R., Cappa, C. D., Middlebrook, A. M., and Schwarz, J. P.: Brown carbon and internal mixing in biomass burning particles, P. Natl. Acad. Sci. USA, 109, 14802-14807, 2012.

Lack, D. A., Bahreini, R., Langridge, J. M., Gilman, J. B., and Middlebrook, A. M.: Brown carbon absorption linked to organic mass tracers in biomass burning particles, Atmos. Chem. Phys., 13, 2415-2422, doi:10.5194/acp-13-2415-2013, 2013.

Lee, A. K. Y., Willis, M. D., Healy, R. M., Onasch, T. B., and Abbatt, J. P. D.: Mixing state of carbonaceous aerosol in an urban environment: single particle characterization using the soot particle aerosol mass spectrometer (SP-AMS), Atmos. Chem. Phys., 15, 1823-1841, doi:10.5194/acp-15-1823-2015, 2015.
Li, C., Ma, Z., Chen, J., Wang, X., Ye, X., Wang, L., Yang, X., Kan, H., Donaldson, D. J., and Mellouki, A.: Evolution of biomass burning smoke particles in the dark, Atmos. Environ., 120, 244 252, 2015.

Li, J., Posfai, M., Hobbs, P. V., and Buseck, P. R.: Individual aerosol particles from biomass burning in southern Africa: 2. Compositions and aging of inorganic particles, J. Geophys. Res.-Atmos., 108, 8484, doi:10.1029/2002JD002310, 2003.

Liu, S., Russell, L. M., Sueper, D. T., and Onasch, T. B.: Organic particle types by single-particle measurements using a time-offlight aerosol mass spectrometer coupled with a light scattering module, Atmos. Meas. Tech., 6, 187-197, doi:10.5194/amt-6187-2013, 2013.

Liu, S., Aiken, A. C., Gorkowski, K., Dubey, M. K., Cappa, C. D., Williams, L. R., Herndon, S. C., Massoli, P., Fortner, E. C., Chhabra, P. S., Brooks, W. A., Onasch, T. B., Jayne, J. T., Worsnop, D. R., China, S., Sharma, N., Mazzoleni, C., Xu, L., Ng, N. L., Liu, D., Allan, J. D., Lee, J. D., Fleming, Z. L., Mohr, C., Zotter, P., Szidat, S., and Prevot, A. S. H.: Enhanced light absorption by mixed source black and brown carbon particles in UK winter., Nat. Commun., 6, 8435-8435, 2015.

Lu, Z., Streets, D. G., Winijkul, E., Yan, F., Chen, Y., Bond, T. C., Feng, Y., Dubey, M. K., Liu, S., Pinto, J. P., and Carmichael, G. R.: Light Absorption Properties and Radiative Effects of Primary Organic Aerosol Emissions, Environ. Sci. Technol., 49, 48684877, 2015.

Massoli, P., Onasch, T. B., Cappa, C. D., Nuamaan, I., Hakala, J., Hayden, K., Li, S., Sueper, D. T., Bates, T. S., Quinn, P. K., Jayne, J. T., and Worsnop, D. R.: Characterization of black carboncontaining particles from soot particle aerosol mass spectrometer measurements on the R/V Atlantis during CalNex 2010, J. Geophys. Res.-Atmos., 120, 2575-2593, 2015.

May, A. A., Levin, E. J. T., Hennigan, C. J., Riipinen, I., Lee, T., Collett Jr., J. L., Jimenez, J. L., Kreidenweis, S. M., and Robinson, A. L.: Gas-particle partitioning of primary organic aerosol emissions: 3. Biomass burning, J. Geophys. Res.-Atmos., 118, 11327-11338, 2013.

McMeeking, G. R., Fortner, E., Onasch, T. B., Taylor, J. W., Flynn, M., Coe, H., and Kreidenweis, S. M.: Impacts of nonrefractory material on light absorption by aerosols emitted from biomass burning, J. Geophys. Res.-Atmos., 119, 12272-12286, 2014.

Mohr, C., Lopez-Hilfiker, F. D., Zotter, P., Prevot, A. S. H., Xu, L., Ng, N. L., Herndon, S. C., Williams, L. R., Franklin, J. P., Zahniser, M. S., Worsnop, D. R., Knighton, W. B., Aiken, A. C., Gorkowski, K. J., Dubey, M. K., Allan, J. D., and Thornton, J. A.: Contribution of Nitrated Phenols to Wood Burning Brown Carbon Light Absorption in Detling, United Kingdom during Winter Time, Environ. Sci. Technol., 47, 6316-6324, 2013.

Ng, N. L., Herndon, S. C., Trimborn, A., Canagaratna, M. R., Croteau, P. L., Onasch, T. B., Sueper, D., Worsnop, D. R., Zhang, Q., Sun, Y. L., and Jayne, J. T.: An Aerosol Chemical Speciation Monitor (ACSM) for Routine Monitoring of the Composition and Mass Concentrations of Ambient Aerosol, Aerosol Sci Technol., 45, 780-794, 2011.

Onasch, T. B., Trimborn, A., Fortner, E. C., Jayne, J. T., Kok, G. L., Williams, L. R., Davidovits, P., and Worsnop, D. R.: Soot Particle Aerosol Mass Spectrometer: Development, Validation, and Initial Application, Aerosol Sci. Technol., 46, 804-817, 2012. 
Paatero, P. and Tapper, U.: Positive matrix factorization: a nonnegative factor model with optimal utilization of error estimate of data values, Environmetrics, 5, 111-126, 1994.

Pagels, J., Dutcher, D. D., Stolzenburg, M. R., McMurry, P. H., Gaelli, M. E., and Gross, D. S.: Fine-particle emissions from solid biofuel combustion studied with single-particle mass spectrometry: Identification of markers for organics, soot, and ash components, J. Geophys. Res.-Atmos., 118, 859-870, 2013.

Rebotier, T. P. and Prather, K. A.: Aerosol time-of-flight mass spectrometry data analysis: A benchmark of clustering algorithms, Anal. Chim. Acta, 585, 38-54, 2007.

Reilly, P. T. A., Lazar, A. C., Gieray, R. A., Whitten, W. B., and Ramsey, J. M.: The elucidation of charge-transfer-induced matrix effects in environmental aerosols via real-time aerosol mass spectral analysis of individual airborne particles, Aerosol Sci. Technol, 33, 135-152, 2000.

Saleh, R., Robinson, E. S., Tkacik, D. S., Ahern, A. T., Liu, S., Aiken, A. C., Sullivan, R. C., Presto, A. A., Dubey, M. K., Yokelson, R. J., Donahue, N. M., and Robinson, A. L.: Brownness of organics in aerosols from biomass burning linked to their black carbon content, Nat. Geosci., 7, 647-650, 2014.

Smith, J. S., Laskin, A., and Laskin, J.: Molecular Characterization of Biomass Burning Aerosols Using High-Resolution Mass Spectrometry, Anal. Chem., 81, 1512-1521, 2009.

Sun, H., Biedermann, L., and Bond, T. C.: Color of brown carbon: A model for ultraviolet and visible light absorption by organic carbon aerosol, Geophys. Res. Lett., 34, L17813, doi:10.1029/2007GL029797, 2007.
Ulbrich, I. M., Canagaratna, M. R., Zhang, Q., Worsnop, D. R., and Jimenez, J. L.: Interpretation of organic components from Positive Matrix Factorization of aerosol mass spectrometric data, Atmos. Chem. Phys., 9, 2891-2918, doi:10.5194/acp-9-2891-2009, 2009.

Washenfelder, R. A., Attwood, A. R., Brock, C. A., Guo, H., Xu, L., Weber, R. J., Ng, N. L., Allen, H. M., Ayres, B. R., Baumann, K., Cohen, R. C., Draper, D. C., Duffey, K. C., Edgerton, E., Fry, J. L., Hu, W. W., Jimenez, J. L., Palm, B. B., Romer, P., Stone, E. A., Wooldridge, P. J., and Brown, S. S.: Biomass burning dominates brown carbon absorption in the rural southeastern United States, Geophys. Res. Lett., 42, 653-664, 2015.

Willis, M. D., Lee, A. K. Y., Onasch, T. B., Fortner, E. C., Williams, L. R., Lambe, A. T., Worsnop, D. R., and Abbatt, J. P. D.: Collection efficiency of the soot-particle aerosol mass spectrometer (SP-AMS) for internally mixed particulate black carbon, Atmos. Meas. Tech., 7, 4507-4516, doi:10.5194/amt-7-4507-2014, 2014.

Willis, M. D., Healy, R. M., Riemer, N., West, M., Wang, J. M., Jeong, C.-H., Wenger, J. C., Evans, G. J., Abbatt, J. P. D., and Lee, A. K. Y.: Quantification of black carbon mixing state from traffic: implications for aerosol optical properties, Atmos. Chem. Phys., 16, 4693-4706, doi:10.5194/acp-16-4693-2016, 2016.

Zhang, Q., Jimenez, J. L., Canagaratna, M. R., Ulbrich, I. M., Ng, N. L., Worsnop, D. R., and Sun, Y.: Understanding atmospheric organic aerosols via factor analysis of aerosol mass spectrometry: a review, Analyt. Bioanalyt. Chem., 401, 3045-3067, 2011. 